\title{
Discovering The Organizational Structure ${ }^{1}$
}

\author{
Marilyn N. Norman and Joy C. Jordan ${ }^{2}$
}

4-H is made possible through the cooperative efforts of the Cooperative State Research, Education and Extension Service of the United States Department of Agriculture (CSREES/ USDA) in Washington D.C., the University of Florida land-grant University Cooperative Extension System and its partnering institutions, and the county governments throughout Florida. These public dollars are extended by private monies raised by the Florida 4-H Foundation, local foundations, individual 4-H staff and volunteers, and the National 4-H Council. Local sponsors, partners, donors, alumni, and others provide resources and incentives for educational programs, events and recognition.

\section{National}

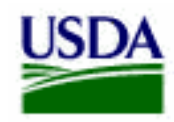

CSREES/USDA (Cooperative State Research, Education and Extension Service of the United States Department of Agriculture) is the National Headquarters for 4-H and provides national leadership for the 4-H program. National administrators and program leaders identify nationwide issues for youth, generate system-wide responses and direct government resources for relevant and effective youth development programs. (www.4hheadquarters.gov)

\section{State}

IFAS tribal colleges are partners with CSREES and administer Extension programs within their state. In 1862, the Morrill Act provided land and partial funding for the development of a university in every state to make higher education accessible to the people of that state. In 1890, the second Morrill Act added 17 historically black colleges to the land grant system. The Equity in Education Land-Grant Status Act of 1994 added 30 tribal colleges to the land grant system. These institutions make up the Land Grant University system within every state. These institutions are the home of 4-H Youth Development Programs. A list of land-grant universities is available at: http://www.reeusda.gov/1700/statepartners/usa.

In Florida, two universities - University of Florida - an 1862 institution and Florida A \& M University - an 1890s institution - support the implementation of 4-H Programs. Each land-grant university has a State 4-H Headquarters much like the USDA. In Florida, this office is located within IFAS at the University of Florida. This program office was established in 1963, merging offices from UF, FAMU and the girls’ programs located at that time at FSU. (http://www.florida4h.org)

\footnotetext{
1 This document is 4-H S FS101.3, one of a series of the Florida 4-H Program, Florida Cooperative Extension Service, Institute of Food and Agricultural Sciences, University of Florida. This material is based upon work supported by the Cooperative Research, Education, and Extension Service, US Department of Agriculture, and K-State Research and Extension, Kansas State University, under special project number 99-EYAR-1-0747. This 4-H 101 Handbook was developed by the 4-H 101 Design Team chaired by Andrea Hutson, USDA/Army Youth Development Project, CSREES/Virginia Tech University. It was adapted for Florida by Marilyn N. Norman and Joy C. Jordan, State 4-H Program. Published May 2006. Please visit the 4-H Website at http://4h.ifas.ufl.edu/Curriculum/index.htm .

2 Marilyn Norman, Associate Professor in Family Youth and Community Sciences, and State 4-H Program Leader, and Joy C. Jordan, Associate Professor in Family, Youth and Community Sciences, Institute of Food and Agricultural Sciences, University of Florida, Gainesville.

The Institute of Food and Agricultural Sciences (IFAS) is an Equal Employment Opportunity - Affirmative Action Employer authorized to provide research, educational information and other services only to individuals and institutions that function without regard to race, creed, color, religion, age, disability, sex, sexual orientation, marital status, national origin, political opinions or affiliations. For information on obtaining other extension publications, contact your county Extension Service office. The Florida 4-H Program is the youth development program of the Florida Cooperative Extension Service/Institute of Food and Agricultural Sciences/University of Florida/Larry R. Arrington, Dean.
} 


\section{County}

Each county has one or more 4-H agent(s) with shared or prime responsibility for the 4-H Youth Development Program. Some counties that include large cities may have an additional office and staff serving just that city. Also, in Florida, the Seminole Tribes employ a 4-H Agent, located in Glades County. The extension office's telephone number may be located in the blue government pages of the local phone book. County funding is provided to support faculty and staff and operations in the local 4-H office.

The 4-H Agents, along with volunteers, start 4-H Clubs in the local communities and provide a variety of programs, activities, events and recognition for 4-H youth, parents and volunteers.

\section{Foundations}

National 4-H Council. This nonprofit organization provides grants, establishes programs/initiatives, designs and publishes curricula and reference materials and creates linkages fostering innovation and shared learning to advance the 4-H youth development movement. It supports USDA and 4-H in building a world in which youth and adults learn, grow and work together as a means for positive change. The Council partners with 4-H at all levels-national, state and county. The Council operates the National 4-H Center in Chevy Chase, MD. (www.fourhcouncil.edu)

Florida 4-H Foundation. This state nonprofit organization provides grants and scholarships to support state and local programs and serves as fiscal agent for 4-H programming. The 4-H Foundation is a Direct Service Organization of the University of Florida, solicits funding for statewide programming and often provides grants to county programs, funding for state-wide awards and scholarships, and support for special events. In Florida, the State 4-H Foundation serves as the fiscal agent for the four residential camps.

The presence of a 4-H county foundations is found in about 30 percent of the counties. However, when counties do have their own foundation, that entity acts in a similar fashion to the state foundation, providing funding and support that is limited to county program efforts. (http://4h.ifas.ufl.edu/Foundation/FoundationHom e.htm)

\section{Organizational Chart}

\section{National Level:}

U.S. Department of Agriculture (USDA):

Congressionally approved home of the organization in which 4-H resides. Administered by: U.S. Secretary of Agriculture: political appointment by the president.

Cooperative State Research, Education and Extension Service (CSREES): One of many agencies within USDA. Has eight units Administered by: Administrator of CSREES.

Families, 4-H and Nutrition: One of eight units within CSREES. Administered by: Deputy Administrator for F4-HN.

Youth Development: One of two units within F4-HN and the National Headquarters for 4-H. Administered by: Director, Youth Development National Program Leaders: Six program leaders provide program and policy leadership and provide financial assistance through securing and managing grants to land grant universities.

\section{State Level:}

Land Grant University: State and Tribal partner with CES. Has many colleges Administered by: University President, along with Senior Vice Presidents for specific colleges or divisions of the University. The University of Florida is a landgrant University.

\section{Cooperative Extension Service (CES):}

Responsible for outreach and bringing knowledge and research generated at the university to address the local needs of citizens in communities across the state. Has many departments or units. Administered by: Director of Cooperative Extension. Extension in Florida is a part of IFAS.

1862 State Extension Specialists: (faculty positions) Responsible for translating research to application and supporting county staff and programs through teaching, assisting in grant preparation and development of curricula and support materials. Extension faculty are a part of the academic department that supports their field of expertise as well as accountable to the extension system. Almost all specialists have a split appointment among research, teaching, and extension. 
1890 Extension Specialists deliver programs in counties or regions of the state where needs exist for specific program priorities. All programs focus on the Extension System's nationwide initiatives and provide educational assistance to limitedresource farmers, families and youth helping them acquire skills that improve the quality of their lives and communities.

1994 Extension Specialists deliver programs to native populations on reservations and in native communities in cities across the state. Florida does not have a 1994 Institution.

Area/District Extension Specialists: some states group counties together to provide additional staff support. These areas or districts have offices in one of the counties within the multiple county area. Florida does not have 4-H District Extension Faculty at this time.

\section{State 4-H Youth Development Office:}

Department or unit within CES responsible for applying knowledge and research related to the growth and development of youth to community youth development efforts across the state. Administered by the State Extension 4-H Leader (sometimes called the Associate or Assistant Director of 4-H Youth Development.) The State 4-H Office at the University of Florida is not a department, but is a unit directly under the Dean for Extension. Extension faculty from every IFAS department may have a percentage appointment to work with youth audiences.

\section{Tribal Extension Youth Development:}

Department in Tribal College responsible for applying knowledge and research related to the growth and development of youth to youth on reservations and in native communities in metropolitan areas. Administered by the Tribal Extension Youth Development Director. Florida does not have a Tribal College.

\section{County Level:}

Land-grant Universities serve audiences in every county in the U.S. through the county extension system.
County Commissioners: Approve the county funding of the Extension budgets. These are governmental elected positions in Florida. County Extension Directors work closely with county governments to insure funding for Extension.

County Extension Advisory Committee and the County 4-H Program Advisory Committees: Provide advice, direction and implementation of all county extension programs. The degree to which county agents are accountable to extension committees varies according to the way in which state funding is distributed to counties in each state. These are appointed positions.

County Extension Faculty: Responsible for coordinating the needs of the county with state and county supported extension outreach and for implementing appropriate program offerings. Usually county offices consist of a team of county agents; typically made up of an Agriculture agent, a Family \& Consumer Sciences Agent and a 4-H agent. Some larger counties may have staff to address additional functions. Smaller counties may have fewer staff that share programmatic responsibilities or may share staff with bordering counties. One of these agents will serve as the County Director. Agents are accountable to both the District Extension Directors (DED) and to the county extension council/advisory committee. Input from State Program Leaders is also provided.

4-H Agent or 4-H Faculty: responsible for the delivery of all aspects of the county 4-H Youth Development program. 4- H agents work with volunteers, parents, youth, schools and community organizations to provide opportunities for youth to master life skills.

Volunteer Leaders: Adults and older youth who serve as club leaders, project leaders, camp counselors etc. Some volunteer leaders work directly with youth and some with other volunteers as trainers and mentors. 